\title{
FRAKSI AIR EKSTRAK DAUN WUNGU (Graptopphyllumpictum L.) SEBAGAI ANTIINFLAMASI TERHADAP TIKUS PUTIH JANTAN
}

\section{WATER EXTRACT FRACTION OF Graptophyllum pictum L.AS Anti-Inflammatory Against Male White Mice}

\author{
Ramadhan Triyandi ${ }^{1}$, Akhmad Rokiban ${ }^{2}$, Catur Setia Pratiwi MS $^{3}$ \\ ${ }^{1}$ Fakultas Kedokteran Program Studi Farmasi Universitas Lampung \\ ${ }^{2}$ Fakultas MIPA, Jurusan Farmasi Universitas Tulang Bawang Lampung \\ Email: ramadhantriyandi0101@fk.unila.ac.id \\ HP. 0812-7342-4287
}

\begin{abstract}
This study aims to determine the anti-inflammatory effect of the water extract of Daun wungu (Graptophyllum pictum L.) extract which was observed from the decrease in the volume of edema of rat's feet which was induced by $1 \%$ carrageenan as much as $0,1 \mathrm{ml}$, was carried out in 25 male white rats divided into 5 groups. Negative controlwas given distilled water given $5 \% \mathrm{Na} C \mathrm{MC}$, diclofenac sodium as a positive control with a dose of $0,9 \mathrm{mg} / 200 \mathrm{~g} \mathrm{BB}$ and water fraction of mungu leaf extract with a dose 1 (1,125 $\mathrm{mg} / \mathrm{kg} \mathrm{bb})$, dose $2(2,25 \mathrm{mg} / \mathrm{kg} \mathrm{bb})$ dan dose $3(4,5 \mathrm{mg} / \mathrm{kg} \mathrm{bb})$. The measurement of edema volume is carried out every hour for six hours after induced carrageenan. From the results of testing the water fraction of wungu leaf extract, \% inhibition showed that the dose group $3(4,5$ $\mathrm{mg} / \mathrm{kg} \mathrm{bb)} \mathrm{had} \mathrm{anti-inflammatory} \mathrm{activity} \mathrm{that} \mathrm{was} \mathrm{comparable} \mathrm{to} \mathrm{the} \mathrm{positive} \mathrm{control} \mathrm{group.}$ Of all dosage variatons in this study the effective dose which has the highest percentage of edema is the dose $3(4,5 \mathrm{mg} / \mathrm{kg} \mathrm{bb})$. Based on the results of statistical analysis, the percentage of edema inhibition data on the water fraction of wungu lear extract from all dose variations showed significant differences with negative controls.
\end{abstract}

Keyword : Graptophyllum pictum L Anti-Inflamasi

\begin{abstract}
Abstrak
Penelitian ini bertujuan untuk mengetahui efek antiinflamasi fraksi air ekstrak daun wungu (Graptophyllum pictum L.) yang ditinjau dari penurunan volume udem telapak kaki tikus yang diinduksi karagenin $1 \%$ sebanyak $0,1 \mathrm{ml}$, dilakukan pada 25 tikus putih jantan yang dibagi menjadi 5 kelompok. Kontrol negatif diberikan aquades yang diberikan Na CMC 5 $\%$, natrium diklofenak sebagai kontrol positif dengan dosis $0,9 \mathrm{mg} / 200 \mathrm{~g}$ bb dan fraksi air ekstrak daun wungu dengan dosis $1(1,125 \mathrm{mg} / \mathrm{kg} \mathrm{bb})$, dosis $2(2,25 \mathrm{mg} / \mathrm{kg} \mathrm{bb})$ dan dosis 3 $(4,5 \mathrm{mg} / \mathrm{kg} \mathrm{bb})$. Pengukuran volume udem dilakukan setiap jam selama enam jam setelah diinduksi karagenan. Dari hasil pengujian fraksi air ekstrak daun wungu, \% inhibisi menunjukkan bahwa kelompok dosis $3(4,5 \mathrm{mg} / \mathrm{kg} \mathrm{BB})$ memiliki aktivitas antiinflamasi yang sebanding dengan kelompok kontrol positif. Dari semua variasi dosis pada penelitian ini dosis efektif yang memiliki persentase ihibisi udem terbesar yaitu dosis $3(4,5 \mathrm{mg} / \mathrm{kg} \mathrm{BB})$. Berdasarkan hasil analisa statistik data persentase inhibisi udem fraksi air ekstrak daun wungu dari semua variasi dosis menunjukkan perbedaan yang bermakna dengan kontrol negatif.
\end{abstract}

Kata kunci : Graptophyllum pictum L. antiinflamasi. 


\section{PENDAHULUAN}

Penggunaan bahan alam, baik sebagai obat maupun tujuan lain cenderung meningkat, terlebih dengan adanya isu back to nature. Obat tradisional dan tanaman obat banyak digunakan masyarakat terutama dalam upaya preventif, promotif dan rehabilitatif. Dewasa ini, obat tradisional merupakan alternati pengobatan yang telah diterima di negara berkembang dan negara maju. Kecenderungan penggunaan obat tradisional adalah karena perubahan lingkungan hidup dan perkembangan pola penyakit (1).

Sementara ini banyak orang beranggapan bahwa penggunaan tanaman obat atau obat tradisional relatif lebih aman dibandingkan obat sintesis. Agar penggunaannya optimal, perlu diketahui informasi yang memadai tentang tanaman obat. Informasi yang memadai akan membantu masyarakat lebih cermat untuk memilih dan menggunakan suatu produk obat tradisional atau tumbuhan obat dalam upaya kesehatan. Pengobatan yang selama ini dilakukan kebanyakan menggunakan obat-obat modern yang pada umumnya memiliki efek samping berbahaya dan relatif mahal (1).

Obat tradisional adalah obat yang dibuat dari bahan atau paduan bahan-bahan yang diperoleh dari tanaman atau mineral yang belum berupa zat murni. Golongan obat yang saat ini tersedia untuk inflamasi (radang) salah satunya adalah obat antiradang golongan non steroid yang sering dikenal dengan obat anti inflamasi non-steroid (AINS), yaitu suatu golongan obat yang memiliki khasiat sebagai analgesik, antipiretik dan anti inflamasi. Penggunaan obat-obat anti inflamasi terutama obat AINS ini dapat menyebabkan terjadinya ulkus peptik, sehingga perlu dikembangkan penggunaan obat tradisional (1).
Inflamasi merupakan suatu kasus yang sering terjadi disekitar kita, mulai dari bayi hingga orang tua. Inflamasi dapat menyertai berbagai penyakit ringan sampai berat. Inflamasi dianggap sebagai suatu penyakit, padahal sebenarnya inflamasi merupakan bentuk nyata dari kerja sistem respon imun. Inflamasi sebagai langkah pertama untuk menghancurkan benda asing dan mikroorganisme serta membersihkan jaringan yang rusak, tubuh mengerahkan elemen-elemen sistem imun ke tempat benda asing dan mikroorganisme yang masuk tubuh atau jaringan yang rusak (2).

Inflamasi atau radang merupakan indicator dari system kekebalan tubuh melawan suatu penyakit, berfungsi menghancurkan, mengurangi, serta melokalisasi agen pencedera maupun jaringan yang cedera. Ciri peradangan akut meliputi edema, kemerahan, panas, dan nyeri. Pada proses radang akut disebabkan oleh pelepasan berbagai macam mediator kimia, seperti produk leukosit, proteaseplasma, aminavaso aktif, dan metabolit asam arakhidonat (2).

Inflamasi merupakan respon jaringan terhadap rangsangan fisik atau kimiawi yang rusak. Rangsangan ini akan menyebabkan timbulnya reaksi radang seperti bengkak dan rasa nyeri (2). Salah satu tumbuhan yang banyak terdapat di Indonesia dan sering dipergunakan sebagai obat adalah tumbuhan wungu (Graptophyl lumpictum (L,). Tumbuhan wungu oleh masyarakat Sumatera dikenal dengan nama pudin, daun perada (Melayu), daun ungu (Jawa), daun tementemen (Sunda), karotong (Madura), temen (Bali), kabi-kabi (Ternate), daun putri (Ambon). Tumbuhan wungu (daun) berkhasiat sebagai peluruh kencing (diuretik), mempercepat mengobati bisul, pencahar ringan (laksatif), dan pelembut kulit (emoliens). Sedangkan bunganya berkhasiat sebagai pelancar haid (3).

Peran senyawa flavonoid yang terdapat dalam ekstrak etanol daun wungu yang memiliki efek anti inflamasi dan 
penghambat pembentukan prostaglandin, kandungan yang terdapat dalam tumbuhan daun wungu adalah alkaloid, tanin, flavonoid, glikosida, saponin (4). Flavanoid adalah suatu kelompok senyawa fenol yang terbanyak terdapat di alam. Senyawa-senyawa ini bertanggung jawab terhadap zat warna merah, ungu, biru, dan sebagian zat warna kuning dalam tumbuhan. Adapun senyawa organik bahan alam yang terbesar jumlahnya, baik dari segi jumlahnya maupun sebarannya. Alkaloid menurut Winterstein dan Trier didefinisikan sebagai senyawa senyawa yang bersifat basa, mengandung atom nitrogen berasal dari tumbuan dan hewan(4). Tujuan penelitian adalah mengetahui ada tidaknya pengaruh fraksi air ekstrak daun wungu (Graptophyl lumpictum (L.)sebagai anti inflamasi pada tikus putih galur wistar.

\section{METODE PENELITIAN}

\section{Alat}

Alat-alat yang akan digunakan dalam penelitian ini adalah rotary evaporator, kertas tempel, kertas saring, alumunium foil, alat gelas (gelas ukur, labu ukur, erlenmeyer, beaker gelas merk Pyrex), corong pisah, wadah botol maserasi, lumpang, sonde oral, timbangan analitik, pletismometer, kandang hewan dan perlengkapannya, dan stopwatch.

\section{Bahan}

Bahan yang digunakan dalam penelitian ini antara lain: daun wungu, etanol $70 \%$, aquadest, karagenin $1 \%$, hewan uji tikus, makanan hewan, air raksa, n-heksan, chloroform dan natrium diklofenak, $\mathrm{Na}$ CMC 5\%.

\section{PROSEDUR}

\section{Pengambilan Bahan}

Bahan yang digunakan berupa daun wungu muda yang diambil di Sukarame Bandar lampung, pemilihan daun wungu yang seumur, yaitu pucuk daun yang masih muda dan segar sebanyak 5 sampai 6 lembar tiap pucuk pohonnya.

\section{Hewan Uji}

Hewan uji yang digunakan berupa tikus putih jantan (Rattus norvegicus) galur Wistar dengan umur kurang lebih 2 bulan dengan berat badan $\pm 200 \mathrm{~g}$ sebanyak 25 ekor yang dibagi menjadi 5 kelompok dan masing-masing kelompok terdiri atas 5 ekor tikus putih yang dipilih secara acak, tikus diadaptasi terlebih dahulu selama seminggu, dan sebelum diuji tikus dipuasakan terlebih dahulu selama 18 jam.

\section{Determinasi Bahan}

Determinasi tanaman dilakukan di Laboratorium Botani Jurusan Biologi FMIPA Universitas Lampung. Hasil determinasi menunjukkan bahwa sampel yang digunakan adalah tanaman daun wungu (Graptophyllumpictum L.)

\section{Pembuatan Simplisia Daun Wungu Muda}

Pucuk daun Wungu yang masih muda dan segar sebanyak 5 sampai 6 lembar tiap pucuk pohonnya, dikumpulkan kemudian dilakukan sortasi basah dan ditimbang. Daun Wungu muda yang digunakan dalam penelitian ini sebanyak $1 \mathrm{~kg}$.. Setelah itu bahan yang diperoleh dipembersihan untuk menghilangkan dari pengotoran yang menempel dan dilakukan penjemuran hingga menjadi simplisia, dan mendapatkan $200 \mathrm{gr}$ simplisia 


\section{Pembuatan Ekstrak Daun Wungu Muda}

Pembuatan ekstrak dilakukan dengan metode maserasi. Simplisia daun wungu muda yang diperoleh semua di-timbang dan mendapatkan sebanyak 200 gram. Kemudian simplisia kering dimaserasi dengan pelarut etanol $70 \%$ sampai terendam kemudian disimpan selama lima hari. Maserasi dihentikan ketika pelarut yang digunakan tidak berubah warna kembali.

Etanol yang diperlukan sebanyak 2 liter dan hasil maserat diperoleh sebanyak 800 $\mathrm{ml}$. Maserat yang dihasilkan kemudian diuapka nmenggunakan rotary evaporator. Kemudian diperoleh ekstrak kental sebanyak $80 \mathrm{gr}$.

\section{Fraksi Air Daun Wungu}

Ekstrak kental yang diperoleh di ad 50ml air dan $100 \mathrm{ml}$ n-heksan, kemudian dikocok dengan corong pisah, sehingga diperoleh fraksi n-heksan dan fraksi air, dipisahkan. Proses ini dilakukan sampai warna pelarut $\mathrm{n}$-heksan tidak berubah setelah dilakukan pengocokan. Fraksi air sisa ditambahkan dengan 100ml kloroform, kemudian dikocok dengan corong pisah dan diperoleh fraksi kloroform dan fraksi air, dipisahkan. Proses ini dilakukan sampai warna pelarut kloroform tidak berubah setelah dilakukan pengocokan. Fraksiair kemudian diuapkan dengan rotari evaporator hingga diperoleh fraksi air sebanyak $25 \mathrm{gr}$.

\section{Pembuatan Bahan Uji}

\section{Pembuatan Suspensi Karagen $1 \%{ }^{\mathrm{b}} \%$}

Karagen ditimbang sebanyak 100 mg, lalu dihomogenkan dengan larutan NaClfisiologis ( $\mathrm{NaCl} 0,9 \%$ ), kemudian masukan kedalam labu ukur $10 \mathrm{ml}$, kemudian cukupkan dengan larutan $\mathrm{NaCl}$ Fisiologis sampai $10 \mathrm{ml}$. Panaskan dan aduk sampai mengembang lalu diamkan selama 1 malam, untuk tiap tikus injeksikan 0,1 $\mathrm{ml}$ karagen $1 \%$ secara suplantar pada telapak kaki kiri tikus(5).

\section{Pembuatan Suspensi Na.CMC 0,5\% b/v}

Na.CMC ditimbang sebanyak 0,1 gram lalu ditaburkan di atas air dengan sebanyak $2 \mathrm{ml}$ (20 kalinya) di dalam lumping panas dibiarkan mengembang selama 15 menit kemudian digerus hingga menjadi massa yang hemegoni dan diencarkan dengan aquadest sampai 20 $\mathrm{ml}$.

\section{Pembuatan Suspense Sediaan Pembanding}

Konversi dosis natrium diklofenak dari manusia ke tikus $=50 \mathrm{mg} \times 0,018=0,9$ $\mathrm{mg} / 200 \mathrm{~g}$ BB. Sediaan yang digunakan adalah tablet voltaren yang beratnya 210 $\mathrm{mg}$ dengan konsentrasi $50 \mathrm{mg}$. Ditimbang $100 \mathrm{mg}$ natrium diklofenak, lalu tambahkan aquadest sampai pada volume $25 \mathrm{ml}$. Ambil larutan tersebut sebanyak $11,81 \mathrm{ml}$, masukkan kedalam lumping dan tambahkan $\mathrm{Na}$ CMC 5\% homogenkan, dan masukkan kedalam labu ukur cukupkan dengan aquadest sampai volume $25 \mathrm{ml}$. Volume pemberian masingmasing $2 \mathrm{ml} / 200 \mathrm{~g} \mathrm{BB}$ tikus.

\section{Perencanaan Dosis}

Pada penelitian sebelumnya dosis yang dipakai dalam ekstrak daun wungu muda sebagai anti inflmasi yaitu :

$$
\begin{array}{ll}
\text { Dosis I } & =1,125 \mathrm{mg} / 200 \mathrm{~g} \mathrm{BB} \\
\text { Dosis II } & =2,25 \mathrm{mg} / 200 \mathrm{~g} \mathrm{BB} \\
\text { Dosis III } & =4,5 \mathrm{mg} / 200 \mathrm{~g} \mathrm{BB}
\end{array}
$$

Untuk menghitung ketersediaan oral pada tikus putih jantan maka digunakan rumus :

$$
\text { VAO }=\frac{\text { Dosis }\left(\frac{\mathrm{mg}}{\mathrm{kg}} \mathrm{BB}\right) \times \text { Berat Badan Hewan }(\mathrm{kg})}{\text { Konsentrasi }\left(\frac{\mathrm{mg}}{\mathrm{ml}}\right)}
$$


Tabel 1 Kelompok perlakuan uji antiinflamasi

\begin{tabular}{|c|c|}
\hline Kelompok & Perlakuan \\
\hline $\begin{array}{c}\text { Kelompok 1 } \\
\text { (Kontrol) }\end{array}$ & $\begin{array}{c}\text { aquades telah } \\
\text { diberikan Na } \\
\text { CMC 5\% }\end{array}$ \\
\hline Kelompok 2 & $\begin{array}{c}\text { fraksi air daun } \\
\text { wungu 1,125 } \\
\text { mg/200g bb }\end{array}$ \\
\hline Kelompok 3 & $\begin{array}{c}\text { fraksi air daun } \\
\text { wungu 2,25 } \\
\text { mg/200g bb }\end{array}$ \\
\hline Kelompok 4 & $\begin{array}{c}\text { fraksiair daun } \\
\text { wungu 4,5 } \\
\text { mg/200g bb }\end{array}$ \\
\hline Kelompok 5 & $\begin{array}{c}\text { natrium } \\
\text { diklofenak 0,9 } \\
\text { mg/200g bb. }\end{array}$ \\
\hline
\end{tabular}

\section{Perhitungan edema kaki tikus}

1) Persenudem

Persenudem dapat ditentukan dengan rumus :

$$
\% \text { udem }=\frac{\mathrm{Vt}-\mathrm{Vo}}{\mathrm{Vo}} \times 100 \%
$$

Keterangan :

Vt :Volume radang setelah pemberian injeksik aragen

Vo :Volume kaki awal sebelum uji karagen

2) Persentase inhibisi radang

Persenin hibisi radang dapat dihitung dengan rumus :

$$
=\frac{a-b}{a} \times 100 \%
$$

Keterangan :

$$
\begin{aligned}
\alpha= & \text { Persenradang rata-rata kelompok } \\
& \text { control } \\
b= & \begin{array}{l}
\text { Persenradang rata- } \\
\text { ratakelompokperlakuanhewanujid } \\
\text { anperbandingan }
\end{array}
\end{aligned}
$$

lengkap (RAL). Data yang di peroleh kemudian di analisis dengan uji one way lanjut BNT ANOVA (distribusi data normal dan varian data harus homogen) dengan tingkat kepercayaan 95\%. (6).

\section{HASIL DAN PEMBAHASAN}

Larutan uji diberikan secara oral kepada masing-masing kelompok perlakuan uji antiinflamasi. Lima belas menit setelah pemberian larutan uji kemudian masingmasing kaki kiri tikus diukur terlebih dahulu lalu diinjeksi dengan karagenan secara subplantar, hasil pengukuran dapat dilihat pada tabel 4.1.

Tabel 4.1 Pengukuran rata-rata tebal kaki kiri tikus sebelum dan sesudah diinduksi karagen

\begin{tabular}{|c|c|c|}
\hline Ulangan & $\begin{array}{c}\text { Rata-rata } \\
\text { tebal kaki } \\
\text { tikus } \\
\text { sebelum } \\
\text { diinduksi } \\
\text { (mm) }\end{array}$ & $\begin{array}{c}\text { Rata-rata } \\
\text { tebal kaki } \\
\text { tikus } \\
\text { sesudah } \\
\text { diinduksi } \\
\text { (mm) }\end{array}$ \\
\hline Kontrol (-) & 4,708 & 0,027 \\
\hline Dosis 1 & 4,92 & 0,069 \\
\hline Dosis 2 & 4,658 & 0,054 \\
\hline Dosis 3 & 4,92 & 0,028 \\
\hline Kontrol (+) & 4,758 & 0,023 \\
\hline
\end{tabular}

Setelah pengukuran kaki kiri tikus sebelum diinduksi karagen selanjutnya di beri perlakuan dengan menyuntikan kaki kiri tikus dengan karagen secara subplantar. Udem yang terbentuk diukur menggunakan plestimometer selama 6 jam dan diukur pada jam ke- 1, 2, 3, 4, 5, dan 6 . Hasil pengukuran selisih kaki kiri tikus sebelum diinduksi karagen dengan kaki sesudah diinduksi karagen didapatkan nilai persentase udem tiap 1 jam selama 6 jam dan rata-rata dapat dilihat pada table 4.2.

\section{Analisa Data}

Pada penelitian ini rancangan yang digunakan adalah rancangan acak 
Tabel 4.2 Nilai \% Udem tiap 1 jam selama 6 jam dan Rata-rata \% Udem

\begin{tabular}{|c|c|c|c|c|c|c|c|}
\hline \multirow{2}{*}{ Perlakuan } & \multicolumn{6}{|c|}{$\%$ Udem tiap 1 jam selama 6 jam } & \multirow{2}{*}{$\begin{array}{c}\text { Rerata\% } \\
\text { Udem }\end{array}$} \\
\hline & 1 & 2 & 3 & 4 & 5 & 6 & \\
\hline Kontrol (-) & $-98,9$ & $-98,9$ & $-99,1$ & $-99,1$ & $-99,4$ & $-96,4$ & $-98,6$ \\
\hline Dosis 1 & $-99,0$ & $-99,2$ & $-99,3$ & $-99,3$ & $-99,1$ & $-99,5$ & $-99,3$ \\
\hline Dosis 2 & $-98,7$ & -99 & $-99,3$ & $-99,4$ & $-99,2$ & $-99,6$ & $-99,3$ \\
\hline Dosis 3 & $-99,5$ & $-99,2$ & $-99,3$ & $-99,3$ & -99.6 & $-99,6$ & $-99,4$ \\
\hline Kontrol $(+)$ & $-99,14$ & $-99,36$ & $-99,48$ & $-94,71$ & -96538 & $-99,53$ & $-98,1$ \\
\hline
\end{tabular}

Berdasarkan hasil tabel diatas kontrol negatif larutan $\mathrm{Na} C M C 5 \%$, yang menunjukkan bahwa pada kelompok kontrol negatif masih memberikan udem yang paling besar dan penurunan udem yang paling kecil dibandingkan pemberian dosis 1, dosis 2, dosis 3 , dan kontrol positif. Berdasarkan hasil tersebut dapat diketahui bahwa pemberian larutan $\mathrm{Na}$ CMC 5\%, tidak memberikan penurunan udem yang berarti dibandingkam kelompok perlakuan lainnya. Nilai ratarata \% udem kontrol positif dengan dosis 3 memberikan udem yang paling kecil, hal ini meunjukan penurunan udem yang signifikan. Nilai \% udem pada dosis 1 , dosis 2 , dan dosis 3 yang paling rendah yaitu pada dosis 3. Selanjutnya untuk mengukur aktivitas antiinflmasi dilihat dari nilai persen (\%) penghambatan inflamasi. Hasil persen (\%) penghambatan inflamasi yang dapat dilihat pada tabel 4.3.

Tabel 4.3 Nilai Rata \% Inhibisi tiap 1 jam selama 6 jam dan Rata \% Udem

\begin{tabular}{|c|c|c|}
\hline Kelompok & $\begin{array}{c}\text { Rata-rata } \\
\% \text { inhibisi } \\
\text { inflamasi }\end{array}$ & $\begin{array}{c}\text { Rata-rata } \\
\% \text { udem }\end{array}$ \\
\hline Kontrol (-) & 0 & $-98,637$ \\
\hline Dosis 1 & $23,4 \%$ & $-99,337$ \\
\hline Dosis 2 & $64,6 \%$ & $-99,349$ \\
\hline Dosis 3 & $73,8 \%$ & $-99,422$ \\
\hline Kontrol (+) & $81,3 \%$ & $-98,115$ \\
\hline
\end{tabular}

Dari hasil tersebut dapat disimpulkan jika kontrol positif memiliki rata-rata \% udem 92,503 dan memiliki persen penghambatan inflamasi $81,3 \%$. Kontrol negatif dengan larutan $\mathrm{Na}$ CMC $5 \%$ memiliki rata-rata udem $-98,800$ dan persen penghambatan inflamasi 0,00 . Hal ini membuktikan bahwa kelompok kontrol positif memiliki persen inhibisi inflamasi yang lebih besar dan memiliki nilai ratarata udem yang lebih kecil jika dibandingkan dengan kontrol negatif $\mathrm{Na}$ CMC 5\%.

Jika kelompok dosis $1(1,125 \mathrm{mg} / 200 \mathrm{~g}$ $\mathrm{BB})$, dosis 2 (2,25 mg/200 $\mathrm{g} \mathrm{BB})$, dan dosis $3(4,5 \mathrm{mg} / 200 \mathrm{~g} \mathrm{BB})$ dibandingkan dengan kelompok negatif maka menunjukkan bahwa ketiga peringkat dosis fraksi memiliki aktivitas antiinflamasi. Jika kelompok dosis $1(1,125 \mathrm{mg} / 200 \mathrm{~g} \mathrm{BB})$ dibandingkan dengan kelompok kontrol positif menunjukkan bahwa dosis $1(1,125$ $\mathrm{mg} / 200 \mathrm{~g}$ BB) memiliki kemampuan antiinflamasi yang lebih rendah dengan kontrol positif.

Jika kelompok dosis $2(2,25 \mathrm{mg} / 200 \mathrm{~g}$ BB) dibandingkan dengan kontrol positif menunjukan bahwa kelompok dosis 2(2,25 mg/200g BB) memiliki kemampuan antiinflamasi yang lebih rendah dengan kontrol positif, terlihat dari persen inhibisi inflamasi. Jika kelompok dosis 3(4,5 $\mathrm{mg} / 200 \mathrm{~g}$ BB) dibandingkan dengan kelompok kontrol positif menunjukkan bahwa kelompok dosis 3 (4,5 mg/200g BB) memiliki aktivitas antiinflamasi yang 
sebanding dengan kelompok kontrol positif. Berdasarkan nilai rata-rata $\%$ udem dan persen inhibisi inflamasi yang diperoleh, kontrol positif memiliki rata-rata $\%$ udem terkecil dan persen inhibisi inflamasi terbesar dibandingkan dengan ketiga kelompok dosis maupun kelompok kontrol negatif.

Apabila kelompok dosis $1(1,125 \mathrm{mg} / 200 \mathrm{~g}$ $\mathrm{BB})$ dibandingkan dengan kelompok dosis $2(2,25 \mathrm{mg} / 200 \mathrm{~g}$ BB) menunjukkan bahwa kelompok dosis $1(1,125 \mathrm{mg} / 200 \mathrm{~g}$ BB) memiliki kemampuan antiinflamasi yang sebanding dengan kelompok dosis 2(2,25 $\mathrm{mg} / 200 \mathrm{~g}$ BB). Jika kelompok dosis 1 (1,125 mg/200g BB) dibandingkan dengan dosis $3(4,5 \mathrm{mg} / 200 \mathrm{~g} \mathrm{BB})$ menunjukan bahwa kemampuan antiinflamasi dosis 1 $(1,125 \mathrm{mg} / 200 \mathrm{~g} \mathrm{BB})$ berbeda dengan dosis $3(4,5 \mathrm{mg} / 200 \mathrm{~g} \mathrm{BB})$.

Berdasarkan nilai persen inhibisi inflamasi, kelompok dosis 3 (4,5 mg/200g BB) memiliki kemampuan efek antiinflamasi yang lebih besar dibandingkan dengan dosis $1(1,125 \mathrm{mg} / 200 \mathrm{~g} \mathrm{BB})$. Selanjutnya jika kelompok dosis 2 (2,25 mg/200g BB) dibandingkan dengan dosis $3(4,5 \mathrm{mg} / 200 \mathrm{~g}$ BB), menunjukkan bahwa kemampuan antiinflamasi dosis $2(2,25 \mathrm{mg} / 200 \mathrm{~g} \mathrm{BB})$ sebanding dengan dosis $3(4,5 \mathrm{mg} / 200 \mathrm{~g}$ $\mathrm{BB})$.

Hasil persen inhibisi inflamasi berturutturut dari dosis kecil ke besar ialah $23,4 \%$; $64,6 \%$; 73,8\%. Hal ini menunjukkan semakin besar nilai \% inhibisi inflamasi, menunjukkan semakin baik efek antiinflamasi pada suatu bahan uji.

Berdasarkan hasil uji statistik dengan metode ANOVA menunjukkan bahwa efek fraksi air ekstrak daun wungu sebagai antiinflamasi berbeda dan semua dosis berpengaruh secara signifikan terhadap efek antiinflamasi dengan hasil $73,8 \%$.

Efektifitas antiinflamasi fraksi air ekstrak daun wungu dapat dilihat pada hasil analisis uji BNT (beda nyata terkecil). Uji BNT ini bertujuan untuk mengetahui ada atau tidaknya perbedaan efektifitas fraksi air ekstrak daun wungu sebagai antiinflamasi terhadap tikus jantan pada setiap dosis yang diberikan. Dosis 3 (45 $\mathrm{mg} / \mathrm{kg}$ ) dan kontrol (+) tidak berbeda nyata dalam efek antiinflamasi terhadap tikus jantan, kemudian dosis $1(1,125 \mathrm{mg} / 200 \mathrm{~g}$ bb) dan dosis $2(2,25 \mathrm{~kg} / 200 \mathrm{~g} \mathrm{bb})$ tidak berbeda nyata dalam efek antiinflamasi terhadap tikus jantan. Sedangkan kontrol (-) yakni Na-CMC menunjukan adanya perbedaan yang nyata pada semua kelompok yaitu dosis $1 \quad(1,125 \mathrm{mg} / 200 \mathrm{~g}$ $\mathrm{bb})$, dosis $2(2,25 \mathrm{~kg} / 200 \mathrm{~g} \mathrm{bb})$ dan dosis 3 $(4,5 \mathrm{mg} / 200 \mathrm{~g} \mathrm{bb})$. Hal ini menunjukkan bahwa fraksi air ekstrak daun wungu menujukkan adanya efek antiinflamasi terhadap tikus jantan.

Adanya kemampuan fraksi air daun wungu dalam menurunkan efek antiinflamasi pada tikus putih jantan yang terinduksi karagen dapat dikaitakan dengan adanya senyawa yang terkandung didalamanya. Senyawa yang biasanya berperan sebagai antiinflamsi ialah flavonoid yang mampu menangkap radikal bebas yang menyebabkan timbulnya respon-respon inflamasi. Inflamasi akut merupakan respon awal terhadap cedera jaringan, hal tersebut terjadi melalui media rilisnya autacoid yang terlibat antara lain histamin, serotonin, bradikinin, prostaglandin dan leukotriene.

Respon imun terjadi bila sejumlah sel yang mampu menimbulkan kekebalan diaktifkan untuk merespon organisme asing atau substansi antigenik yang terlepas selama respon terhadap inflamasi akut serta kronis. Akibat respon imun bagi tuan rumah mungkin menguntungkan, misalnya menyebabkan organisme penyerang difagositosis atau dinetralisir. Sebaliknya akibat tersebut juga dapat bersifat merusak bila menjurus pada inflamasi kronis tanpa penguraian dari proses cedera yang mendasarinya. Inflamasi kronis menyebabkan keluarnya sejumlah mediator yang tidak menonjol dalam respon akut. Salah satu kondisi yang paling penting yang melibatkan mediator ini adalah artritis rheumatoid, dimana inflamasi kronis menyebabkan 
sakit dan kerusakan pada tulang dan tulang rawan yang bisa menjurus pada ketidak mampuan untuk bergerak (7).

Bila membran sel mengalami kerusakan oleh suatu rangsang kimiawi, fisik, atau mekanis, maka enzim fosfolipase diaktifkan untuk mengubah fosfolipida yang terdapat di situ menjadi asam arachidonat, kemudian untuk sebagian diubah oleh enzim cyclooxygenase menjadi asam endoperoksida dan seterusnya menjadi zat zat prostaglandin. Bagian lain dari asam arachidonat diubah oleh enzyme lipooksigenase menjadi zat leukotrien. Baik prostaglandin maupun leukotrien bertanggung jawab bagi sebagian besar dari gejala peradangan. Cyclo-oxygenase terdiri dari 2 isoenzym yakni COX-1 dan COX-2. COX-1 terdapat di kebanyakan jaringan, antara lain di pelat-pelat darah, ginjal, dan saluran cerna. Zat ini berperan pada pemeliharaan perfusi ginjal, homeostasevaskuler, dan melindungi lambung membentuk bikarbonat dan lendir serta menghambat produksi asam. $\mathrm{COX}-2$ dalam keadaan normal $\mathrm{t}$, tetapi dibentuk selama proses peradangan oleh sel-sel radang dan kadarnya dalam sel meningkat sampai 80 kali (8).

\section{KESIMPULAN DAN SARAN}

\section{KESIMPULAN}

Berdasarkan hasil yang diperoleh dapat diambil kesimpulan sebagai

berikut :

1. Fraksi air ekstrak daun wungu dapat memberikan efek antiinflamasi(Graptophyllumpictum L.).

2. Fraksi air ekstrak daun wungu (Graptophyllumpictum L.) dosis 1, dosis 2 dan dosis 3 memiliki efek antiinflamasi dan efek antiinflamasi yang paling besar adalah pada dosis

\section{SARAN}

Disarankan pada pembaca supaya melakukan pemisahan senyawa agar diketahui senyawa metabolit yang lebih berperan memberikan aktivitas antiinflamasi dan membuat formulasi sediaan fraksi daun wungu

\section{UCAPAN TERIMAKASIH}

Terimakasih kepada Fakultas Kedoteran Universitas Lampung dan Laboraratorium Farmakologi Toksikologi yang telah membantu terselenggaranya penelitian ini.

\section{DAFTAR PUSTAKA}

1. Katno, Pramono S..Tingkat Manfaat dan Keamanan Tanaman Obat dan obat Tradisional. Balai Penelitian Tanaman Obat Tawamangu Fakultas Farmasi, Universitas Gajah Mada. Yogyakarta. 2005.

2. Wilmana, P. F..Analgetik Antiinflamasi Nonsteroid dan Obat Pirai dalam Ganiswarna. S. G. Farmakologi dan Terapi. Edisi IV. Bagian Farmakologi. Fakultas Kedokteran Universitas Indonesia. Jakarta.1995.

3. Dalimartha. Atlas Tumbuhan IndoNesia, Jilid III, Trubus Agriwidya Jakarta. 1999.

4. Kalsum, U. Peran flavonoid Graptophyllum pictum L Griff (daun wungu) Sebagai anti Inflamasi dan Hambatan Sintesa Prostaglandin. Universitas Brawijaya. 1996.

5. Mycek, MJ.Farmakologi Ulasan Bergambar. Jakarta : Widya Medika.2001.

6. Siregar S. Statistik Parametik untuk Penelitian Kuantitatif. Jakarta. PT Bumi Aksara. 2013 
7. Katzung, B.Farmakologi Dasar dan Klinik, Edisi 8. Jakarta : Salemba Medika.2002.

8. Tjay, T. H. Dan Raharja, K.Obat-obat Penting : Khasiat Penggunaan dan Efek Sampingnya Cetakan ke-5, Departemen Kesehatan Republik Indonesia, Jakarta. 2002 